\title{
Filsafat Ilmu Manajemen dan Implikasi dalam Praktik
}

\author{
M. Elfan Kaukab \\ Email: elvankaukab@yahoo.com \\ Program Doktor Ilmu Manajemen (DIM) \\ Universitas Jenderal Soedirman
}

\begin{abstract}
This paper explains the development of a management practice framework with the philosophy of the social sciences as analysis approach, especially in the field of management as a basic reference. The tendency of epistemological and ontological understanding of managers will give a different perspective to the organization. This framework can be used to construct a taxonomy that is able to identify the philosophical paradigm as the basis in developing good management practices, so that managers can understand the risks that may arise in the organization due to their lack of understanding the fundamentals of philosophy in management science. Four philosophical frameworks that integrate perspectives, research methods, practices, and behaviors in management become new perspective models, i.e. naturalist-agency perspective, naturalist-structuralist perspective, hermeneutic-agency perspective, and hermeneutic-structuralist perspective. Coherent philosophical approach is necessary in the application and development of management practices.
\end{abstract}

Keywords: Management, Philosophy of Management Science, Management Praxis

\begin{abstract}
Abstrak Tulisan ini menjelaskan mengenai pengembangan kerangka kerja praktik manajemen dengan pendekatan analisis filsafat ilmu sosial khususnya dalam bidang manajemen sebagai dasar acuannya. Kecenderungan pemahaman epistemologis dan ontologis oleh seorang manajer akan memberikan cara pandang yang berbeda terhadap organisasi. Kerangka kerja ini dapat digunakan untuk membangun sebuah taksonomi yang mampu mengidentifikasi paradigma filosofis sebagai dasar dalam mengembangkan praktik manajemen yang baik, sehingga para manajer dapat memahami risiko yang mungkin muncul dalam organisasi yang disebabkan kekurangpahaman mereka akan dasar-dasar filsafat dalam ilmu manajemen. Empat kerangka perspektif yang mengintegrasikan filsafat, metode riset, praktik, dan perilaku dalam manajemen menjadi model perspektif baru yaitu perspektif naturalist agency, perspektif naturalist structuralis, perspektif hermeneutic agency, dan perspektif hermeneutic structuralist. Pendekatan filosofis yang koheren ini diperlukan dalam aplikasi dan pengembangan praktik manajemen.
\end{abstract}

Kata Kunci: Manajemen, Filsafat Ilmu Manajemen, Praktik Manajemen 


\section{PENDAHULUAN}

Tata cara pengelolaan manajemen organisasi dalam praktik mengalami perkembangan pesat sejalan dengan ragam organisasi yang semakin komplek. Ilmu manajemen sebagai acuan dasar dalam menciptakan formula-formula manajerial terus dikembangkan menyesuaiakan pola organisasi yang digunakan sehingga mampu mencapai kinerja yang maksimal. Para pakar manajemen mulai merancang dan membedakan satu organisasi dengan organisasi yang lain dengan memahami konsep yang dianggap sebagai kerangka kerja terbaik.

Semua pendekatan yang digunakan dalam pengembangan ilmu manajemen memiliki nilai saing, kepercayaan, dan sikap yang dianggap mampu memberikan kontribusi terbaik dalam praktik manajemen. Nilai-nilai ini akan dianut oleh para manajer dalam menjalankan organisasi, menghadapi persaiangan, dan menyikapi perilaku yang berubah-ubah. Adanya persaingan dunia mendasari para manajer mulai memahami ilmu manajemen secara filosofis sebagai sikap aktif mendalami akar keilmuan apa yang sesuai dengan konsep aplikasi organisasi dan keilmuan yang mampu mengakomodir tindakantindakan manusia sebagai pelakunya.

Tulisan ini menerapkan konsep kerangka kerja dengan Filsafat Ilmu Sosial khususnya dalam bidang ilmu manajemen sebagai dasar dalam melakukan eksplorasi disposisi filosofis yang akan memunculkan persepsi berbeda mengenai praktik manajemen yang selama ini dianggap sudah baik. Dengan membandingkan beberapa perspektif dapat memunculkan pola-pola baru yang dapat digunakan sebagai kerangka kerja yang lebih baik dan dapat menjadi acuan baru bagi para manajer dalam praktik.

Tujuan dari tulisan ini pertama untuk mengidentifikasi paradigma filosofis dalam melihat pola praktik manajemen yang dianggap sudah baik. Kedua, mengartikulasi risiko yang mungkin terjadi dalam pendekatan-pendekatan manajemen sehingga dapat mengidentifikasi kelemahan-kelemahan dasar filosofis yang dimiliki oleh para manajer. Ketiga, menerapkan perkembangan terakhir filsafat ilmu-ilmu sosial dan didalamnya terdapat filsafat ilmu manajemen untuk membangun fondasi metodologis seperangkat pola manajemen dalam praktik. Tujuan terakhir adalah untuk menjelaskan implikasi dari analisis untuk pengambangan manajemen. 


\section{KERANGKA TEORITIS}

\section{Filsafat Ilmu Manajemen}

Filsafat dan Ilmu merupakan dua kata yang saling berkaitan baik secara substansial maupun historis. Kelahiran suatu ilmu tidak dapat dipisahkan dari peranan filsafat, sebaliknya perkembangan ilmu memperkuat keberadaan filsafat. Filsafat ilmu pengetahuan berkaitan dengan pembahasan bagaimana disiplin ilmu tertentu menghasilkan pengetahuan, memberikan penjelasan dan prediksi, serta pemahaman yang melatarbelakangi suatu disiplin ilmu. Dengan kata lain, filsafat ilmu pengetahuan merupakan telaah secara filsafati yang ingin menjawab beberapa pertanyaan mengenai hakikat sains empirikal, seperti obyek apa yang ditelaah ilmu? Bagaimana wujud yang hakiki dari obyek tersebut? Bagaimana hubungan antara obyek tersebut dengan daya tangkap manusia (seperti berpikir, merasa, dan mengindera) yang membuahkan pengetahuan? Pertanyaan-pertanyaan ini disebut landasan ontologism. Kemudian muncul pertanyaan lain mengenai bagaimana proses yang memungkinkan diperolehnya pengetahuan yang berupa ilmu? Bagaimana prosedurnya? Hal-hal apa yang harus diperhatikan agar kita mendapatkan pengetahuan yang benar? Apa yang disebut kebenaran itu? Apa kriterianya? Cara/teknik/sarana apa yang membantu kita dalam mendapatkan pengetahuan yang berupa ilmu? Pertanyaan-pertanyaan ini disebut landasan epistemologis. Pertanyaan terakhir adalah untuk apa pengetahuan yang berupa ilmu itu dipergunakan? Bagaimana kaitan antara cara penggunaan tersebut dengan kaidah-kaidah moral? Bagaimana penentuan obyek yang ditelaah berdasarkan pilihan-pilihan moral? Bagaimana kaitan antara teknik prosedural yang merupakan operasionalisasi metode ilmiah dengan norma-norma moral/profesional? Pertanyaan-pertanyaan ini adalah landasan aksiologis.

Jika didefinisikan, filsafat ilmu pengetahuan merupakan cabang filsafat yang membahas tentang sejarah perkembangan ilmu pengetahuan, pengetahuan, metode-metode ilmiah, serta sikap etis yang harus dikembangkan oleh para ilmuwan, yang berfungsi sebagai sarana pengujian penalaran sains, merefleksi, menguji, mengkritik asumsi dan metode keilmuan; serta memberikan landasan logis terhadap metode keilmuan (Judistira, 2006; Salmon et. al., 1992; dan www.wikipedia.org). Dalam ilmu manajemen, keberadaan ilmu filsafat sebagai akar munculnya teori-teori manajemen sehingga dapat berdiri sebagai ilmu yang memiliki aspek metodologis dan epistemologis yang menghasilkan pengetahuan empiris. Manajemen belum memiliki definisi yang mapan dan diterima secara universal. Mary Parker Follet, misalnya, mendefinisikan manajemen sebagai seni menyelesaikan pekerjaan melalui orang lain. Definisi ini berarti bahwa seorang manajer bertugas 
mengatur dan mengarahkan orang lain untuk mencapai tujuan organisasi. Ricky W.Griffin mendefinisikan manajemen sebagai sebuah proses perencanaan, pengorganisasian, pengkoordinasian, dan pengontrolan sumber daya untuk mencapai sasaran (goals) secara efektif dan efesien. Efektif berarti bahwa tujuan dapat dicapai sesuai dengan perencanaan, sementara efisien berarti bahwa tugas yang ada dilaksanakan secara benar, terorganisir, dan sesuai dengan jadwal.

\section{Kerangka Filosofis dalam Analisis Praktik Manajemen}

Seorang manajer harus memiliki kemampuan dalam memilih ilmu pengetahuan secara selektif yang akan diaplikasikan dalam praktik pengelolaan sebuah organisasi. Manajer juga harus mampu memahami dan mengontrol perilaku orang lain yang terlibat di dalam organisasi. Kemampuan tersebut akan menghasilkan nilai dalam diri seorang manajer sehingga dapat menangani permasalahan yang muncul bahkan dalam kasus-kasus ekstrim organisasi. Kemampuan menyeleksi ilmu pengetahuan dalam praktik juga dapat menjadi kekuatan homogenisasi dari heterogenitas budaya, opini, dan wewenang dalam organisasi sehingga tercipta prinsip dan tujuan organisasi secara general.

Pemahaman keilmuan yang tepat bagi seorang manajer akan memberikan kemampuan berpikir rasional kognitif dalam pencapaian tujuan organisasi dan kemampuan berpikir rasional komunikatif dalam menangani masalah-masalah normatif (Dixon dan Dogan, 2012). Pemikiran yang dilakukan oleh seorang manajer dengan melakukan interaksi baik dengan intern maupun ekstern organisasi akan menghasilkan seperangkat hirarki tersetruktur mengenai keyakinan, nilai, dan norma manajemen organisasi.

Manajer yang mampu menghadapi konflik dalam organisasi dan bangga pada organisasinya tergantung dari kecenderungan pemahaman epistemologis dan ontologis mereka. Kecenderungan epistemologis memperlihatkan cara pandang manajer pada apa yang mereka ketahui, bagaimana hal itu diketahui, dan standar kebenaran apa yang bisa digunakan. Sedangakan kecenderungan ontologis menunjukkan anggapan seorang manajer mengenai sifat makhluk, bagaimana mereka ada, kondisi keberadaan mereka, dan kemungkinan penyebab mereka ada (Dixon, 2002).

\section{Disposisi Epistemologis}

Disposisi epistemologis terfokus pada kemampuan seseorang dalam memahami fakta dengan cara mempercayai atau memegang keyakinan. Sikap ini akan berangsurangsur menjadi perilaku ketika dikombinasikan dengan keinginan dan sikap mental 
lainnya. Keyakinan dapat menjadi pengetahuan melalui tahapan dan kriteria dengan standar ilmu pengetahuan. Perdebatan epistemologis terjadi dalam ilmu-ilmu sosial yang menyangkut hubungan antara objektif dan subjektif. Menurut Hollis (1994) terdapat dua pendekatan epistemologis yaitu naturalism dan hermeneutika.

Naturalisme merupakan teori yang menerima "nature" (alam) sebagai keseluruhan realitas. Istilah "nature" telah dipakai dalam filsafat dengan bermacam-macam arti, mulai dari dunia fisik yang dapat dilihat oleh manusia, sampai kepada sistem total dari fenomena ruang dan waktu. Natura adalah dunia yang diungkapkan kepada kita oleh sains alam. Istilah naturalisme adalah sebaliknya dari istilah supernaturalisme yang mengandung pandangan dualistik terhadap alam dengan adanya kekuatan yang ada (wujud) di atas atau di luar alam (Harold H. Titus et.al. 1984). Pendekatan naturalisme menggunakan dasar pengetahuan sosial dengan dua tradisi utama yaitu positvisme dan realisme.

Di bawah naungan payung positivisme, ditetapkan bahwa objek ilmu pengetahuan maupun pernyataan-pernyataan ilmu pengetahuan (Scientific Proporsition) haruslah memenuhi syarat-syarat (Kerlinger, 1973) sebagai berikut: dapat di/ter-amati (observable), dapat di/ter-ulang (repeatable), dapat di/ter-ukur (measurable), dapat di/ter-uji (testable), dan dapat di/ter-ramalkan (predictable). Paradigma positivisme telah menjadi pegangan para ilmuwan untuk mengungkapkan kebenaran realitas. Kebenaran yang dianut positivisme dalam mencari kebenaran adalah teori korespondensi. Teori korespondensi menyebutkan bahwa suatu pernyataan adalah benar jika terdapat fakta-fakta empiris yang mendukung pernyataan tersebut. Atau dengan kata lain, suatu pernyataan dianggap benar apabila materi yang terkandung dalam pernyataan tersebut bersesuaian (korespodensi) dengan obyek faktual yang ditunjuk oleh pernyataan tersebut.

Realisme adalah suatu bentuk yang dapat merepresentasikan kenyataan. Realisme terpusat pada pertanyaan tentang representasi, yaitu tentang bagaimana dunia dikonstruksi dan disajikan secara sosial kepada dan oleh diri kita. Inti realisme dapat dipahami sebagai kajian tentang budaya sebagai praktik-praktik pemaknaan dari representasi. Hal ini berarti bahwa kita harus mempelajari asal-usul tekstual dari makna. Hal ini juga menuntut kita untuk meneliti cara-cara tentang bagaimana makna diproduksi dalam beragam konteks. Dalam pemikiran filsafat, realisme berpandangan bahwa kenyataan tidaklah terbatas pada pengalaman inderawi ataupun gagasan yang terbangun dari dalam. Dengan demikian realisme dapat dikatakan sebagai bentuk penolakan terhadap gagasan ekstrim idealisme dan empirisme. Dalam membangun ilmu pengetahuan, realisme memberikan teori dengan metode induksi empiris. Gagasan utama dari realisme dalam konteks pemerolehan 
pengetahuan adalah bahwa pengetahuan didapatkan dari dual hal, yaitu observasi dan pengembangan pemikiran baru dari observasi yang dilakukan. Dalam konteks ini, ilmuwan dapat saja menganalisa kategori fenomena-fenomena yang secara teoritis eksis walaupun tidak dapat diobservasi secara langsung.

Pendekatan epistemologi kedua yaitu hermeneutika. Dalam Webster's Third New International Dictionary dijelaskan definisi hermeneutika yaitu studi tentang prinsipprinsip metodologis interpretasi dan eksplanasi, khususnya studi tentang prinsip-prinsip umum interpretasi Bibel. Setidaknya ada tiga bidang yang sering akrab dengan term hermeneutika yaitu teologi, filsafat, dan sastra. Persoalan utama hermeneutika terletak pada pencarian makna teks, apakah makna obyektif atau makna subyektif. Perbedaan penekanan pencarian makna pada ketiga unsur hermeneutika adalah penggagas, teks dan pembaca, menjadi titik beda masing-masing hermeneutika. Titik beda itu dapat dikelompokkan menjadi tiga kategori hermeneutika yaitu hermeneutika teoritis, hermeneutika filosofis, dan hermeneutika kritis.

Hermeneutika teoritis. Bentuk hermeneutika seperti ini menitikberatkan kajiannya pada problem "pemahaman", yakni bagaimana memahami dengan benar. Sedang makna yang menjadi tujuan pencarian dalam hermeneutika ini adalah makna yang dikehendaki penggagas teks. Kedua hermeneutika filosofis. Problem utama hermeneutika ini bukanlah bagaimana memahami teks dengan benar dan obyektif sebagaimana hermeneutika teoritis. Problem utamannya adalah bagaimana "tindakan memahami" itu sendiri. Dan ketiga hermeneutika kritis. Hermeneutika ini bertujuan untuk mengungkap kepentingan di balik teks. hermeneutika kritis menempatkan sesuatu yang berada di luar teks sebagai problem hermeneutiknya.

\section{Disposisi Ontologis}

Ontologi diartikan dengan meta fisika umum yaitu cabang filsafat yang mempelajari tentang sifat dasar dari kenyataan yang terdalam membahas asas-asas rasional dari kenyataan (Kattsoff, 1986). Dengan kata lain, permasalahan ontologi adalah menggali sesuatu dari yang nampak. Dalam persoalan ontologi, sebuah objek dapat dipaparkan melalui lima butir pertanyaan. Pertama, objek tersebut bersifat satu atau banyak. Kedua, bersifat transenden atau imanen. Ketiga, permanen atau baharu (berubah-ubah). Keempat, jasmani atau rohani. Kelima, objek tersebut bernilai atau tidak. Dalam struktur realitas, ilmu sosial berada dalam level ke empat. yakni merupakan ilmu yang membahas dalam ranah relasi atas manusia. Dari situ dapat diketahui bahwa ilmu sosial merupakan ilmu 
yang bersifat banyak (plural). Sebab, ilmu sosial berjalan dalam pembahasan relasi atas manusia, dan pada dasarnya, manusia bersifat kompleks, berbeda satu sama lain. Setiap pribadi memiliki modelnya masing-masing, oleh karena itu, ilmu sosial pun bersifat banyak atau plural.

Setelah mengetahui objek dari ilmu sosial, dapat ditarik kesimpulan bahwa ilmu sosial merupakan ilmu yang berada dalam struktur-struktur, dan mengambil bagian yang menentukan proses alam (imanen). Ilmu sosial bukanlah sesuatu yang berada jauh di atas hal-hal yang terdapat dalam pengalaman (transenden), seperti halnya Tuhan. Berbeda dengan ilmu alam, ilmu sosial cendrung bersifat berubah-ubah, ilmu sosial memandang kebenaran tidak berifat mutlak, yang ada hanya mendekati kebenaran, Ia bergantung pada keadaan objek yang dikaji, dalam ilmu sosial saat ini, belum tentu sama dengan beberapa abad lalu atau yang akan datang. Ilmu sosial tidak dapat diprediksi seperti halnya ilmu alam karena objek-objek dari ilmu sosial berbeda dalam bentuk, struktur serta sifatnya.

Dari dikotomi epistemologis dan ontologis muncul seperangkat metodologi yang dapat menghasilkan sebuah rerangka yang digunakan untuk melihat ilmu sosial secara filosafis.

Gambar 1.

Dasar Epistemologis dan Ontologis dari Proposisi Manajemen yang Baik

\begin{tabular}{|c|c|c|c|}
\hline & \multicolumn{2}{|c|}{ Epistemologi } \\
\hline & & Naturalisme & Hermeneutik \\
\hline $\begin{array}{l}\frac{0}{00} \\
\frac{0}{0} \\
\stackrel{0}{0}\end{array}$ & 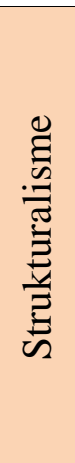 & $\begin{array}{l}\text { Naturalis Strukturalisme } \\
\text { Menganggap bahwa dunia sosial } \\
\text { yang bersifat objektif dapat } \\
\text { diketahui dengan metode ilmiah } \\
\text { dimana struktur menjalankan } \\
\text { kekuatan melalui agen, sehingga } \\
\text { perilaku manusia dapat diprediksi. } \\
\text { "Manajemen Proses" }\end{array}$ & $\begin{array}{l}\text { Hermeneutik Strukturalisme } \\
\text { Menganggap bahwa dunia sosial } \\
\text { yang bersifat subjektif diketahui } \\
\text { hanya sebagai bentukan } \\
\text { masyarakat dengan melihat } \\
\text { perilaku mereka yang dapat } \\
\text { diprediksi dan dapat ditentukan. } \\
\text { "Manajemen Inklusi/keterlibatan" }\end{array}$ \\
\hline
\end{tabular}




\begin{tabular}{|l|l|l|l|}
\hline & $\begin{array}{l}\text { Naturalis Agensi } \\
\text { Menganggap bahwa dunia sosial } \\
\text { yang bersifat objektif dapat } \\
\text { diketahui dengan metode ilmiah } \\
\text { dimana orang-orang sebagai agen } \\
\text { dari tindakan mereka dengan } \\
\text { perilaku mereka yang dapat } \\
\text { diprediksi dengan tidak membatasi } \\
\text { kepentingan mereka. }\end{array}$ & $\begin{array}{l}\text { Hermeneutik Agensi } \\
\text { Menganggap bahwa dunia sosial } \\
\text { yang bersifat subjektif dapat } \\
\text { diketahui melalui apa yang orang- } \\
\text { orang percaya dengan adanya } \\
\text { pembatasan pada persepsi mereka } \\
\text { sehingga perilaku mereka dapat } \\
\text { diprediksi. }\end{array}$ \\
"Manajemen Hasil" & \\
"Manajemen Keberlangsungan" \\
\hline
\end{tabular}

(Dixon, J. and Dogan, R., 2003)

\section{METODE RISET}

Metode riset yang digunakan adalah metode inkuiri filisofis yaitu melibatkan penggunaan mekanisme analisis intelektual untuk memperjelas makna, membuat nilai-nilai menjadi nyata, mengidentifikasi etika, dan studi tentang hakikat pengetahuan. Peneliti filosofis mempertimbangkan ide atau isu-isu dari semua perspektif dengan eksplorasi ekstensif atas literatur, menguji atau menelaah secara mendalam makna konseptual, merumuskan pertanyaan, mengajukan jawaban, dan menyarankan implikasi atas jawabanjawaban itu.

\section{PEMBAHASAN}

\section{Taksonomi Filosofis Mengenai Praktik Manajemen yang Baik}

Pada Gambar 1. menunjukkan pengelompokan metodologis yang mendukung terbentuknya kerangka koheren yang mengintegrasikan filsafat, metode riset, praktik, dan perilaku dalam manajemen. Pada bagian predisposisi terdiri dari bentuk-bentuk penalaran dan bagian nomologi terdiri dari asumsi-asumsi mengenai bagaimana kecenderungan orang untuk berperilaku dalam situasi tertentu. Setiap bagian memberikan arahan bagaimana pengelolaan manajemen organisasi yang baik. Namun demikian pemikiran filosofis ini tentu tidak selalu sempurna. Manajer yang dalam pengelolaan organisasinya menggunakan pola diluar kerangka epistemologi baik naturalis maupun hermeneutik akan menggunakan pola lain dari kerangka epistemologi yang ditawarkan. Demikian juga ketika para manajer tidak sesuai dengan kerangka ontologi baik strukturalis maupun agensi akan menggunakan pola lain dari kerangka ontologi yang ditawarkan. 
Manajer akan menggunakan pola-pola yang disesuaikan dengan kondisi organisasi yang memiliki latar belakang berbeda-beda baik dari kultur, adat istiada, aturan, dan model manajemen. Penyesuaian pola tentunya diharapkan dapat menciptakan organisasi yang unggul dan mudah dijalankan serta diterima oleh anggota organisasi.

\section{Perspektif Naturalist Agency}

Manajer cenderung menggunakan pola naturalist agency dalam mengelola organisasi yang berorientasi pada kewirausahaan (Mintzberg, 1989), terutama para manajer yang fokus pada hasil ahir. Manajer menggunakan pola ini karena sifat organisasi (perusahan) sangat dasar dimana hasil (outcome/output) merupakan inti dari ahir sebuah tujuan. Selain itu, organisasi ini juga belum rumit dalam struktur organisasinya, cenderung belum formal, dan belum dilakukan sentralisasi didalamnya. Dalam matrik pembuatan keputusan stratejik yang dicetuskan oleh Thomson (1967), para manajer cenderung akan menilai keberhasilan organisasi dengan melihat nilai saja dan tidak menghiraukan penyebab terjadinya hasil tersebut (tidak melihat bagaimana proses pencapain hasil).

Manajer penganut aliran naturalist agency memiliki gaya kepemimpinan developer (pembangun) (Nichols, 1986) dengan menggunakan sistem manajemen konsultatif dimana pola yang dikembangkan adalah hubungan yang rendah antar anggota organisasi dan perilaku penugasan yang rendah pula (Likert, 1967). Dalam gaya kepemimpinan ini, seorang manajer hanya akan memberikan batasan tujuan kemudian keputusan pelaksanaan akan banyak dilakukan oleh anggota organisasi tentunya dengan mengindahkan hak dan wewenang yang dimiliki masing-masing anggota. Otonomi tugas yang diberikan kepada para anggota akan memberi ruang kebebasan dalam berkreasi dan pengambilan keputusan namun tetap ada pertanggungjawabannya.

\section{Perspektif Naturalist Structuralist}

Manajer dengan kecenderungan mengikuti gaya naturalist stucturalist akan mengelola organisasi dengan pola birokratis (Weber, 1947) dimana perhatian utama pada input dan proses dalam mencapai tujuan organisasi. Berbanding terbalik dengan naturalist agency, perspektif naturalist structuralist menekankan pada mekanisme struktur yang ketat dan komplek, formalitas dan sentralisasi yang tinggi. Dalam model perspektif ini, manajer memastikan bahwa organisasi dapat dikelola secara terpusat dengan tugas anggota yang lebih spesifik, menjaga ketertiban, dan memiliki kesatuan serta kontrol yang baik. Model 
top-down management sangat kental dalam perspektif ini sehingga anggota dapat diarahkan lebih mudah dalam mencapai tujuan organisasi dengan keloyalan yang tinggi.

Manajer akan menganggap organisasi telah berjalan dengan baik jika proses dalam menjalankan organisasi sudah sesuai dengan aturan dan kepatuhan karyawan juga baik. Proses administrasi akan diawasi dengan sangat ketat dan jelas pembagian tugas masing-masing anggota organisasi. Hal ini dapat dilakukan karena perilaku manusia mudah diprediksi jika telah dibatasi aturan-aturan yang mengikat.

Gaya kepemimpinan manajer pada perspektif ini adalah gaya kepemimpinan parental (Nichols, 1986). Kepemimpinan parental lebih diidentikkan dengan kepemimpinan yang kebapakan dengan sifat-sifat sebagai berikut: (1) mereka menganggap bawahannya sebagai manusia yang tidak/belum dewasa, atau anak sendiri yang perlu dikembangkan, (2) mereka bersikap terlalu melindungi, (3) mereka jarang memberikan kesempatan kepada bawahan untuk mengambil keputusan sendiri, (4) mereka hampir tidak pernah memberikan kesempatan kepada bawahan untuk berinisiatif, (5) mereka memberikan atau hampir tidak pernah memberikan kesempatan pada pengikut atau bawahan untuk mengembangkan imajinasi dan daya kreativitas mereka sendiri, (6) selalu bersikap maha tahu dan maha benar.

\section{Perspektif Hermeneutic Agency}

Dalam perspektif hermeneutic agency, manajer akan mengelola organisasi dengan melembagakan struktur birokrasi dengan perhatian utama pada input dan proses (Morgan, 1986). Karakteristik dari perspektif ini adalah kerjasama yang sangat rendah dan aturan organisasi yang mengikat dan ketat. Struktur birokrasi akan memungkinkan adanya pengelolaan organisasi dengan kompleksitas, formalitas, dan sentralisasi yang tinggi. Manajer memegang peranan sangat kuat karena pengambilan keputusan dilakukan dengan kurang melibatkan anggota dalam organisasi.

Gaya kepemimpinan yang sesuai bagi manajer penganut hermeneutic agency adalah gaya driver (penggerak) (Nichols, 1986) dengan sistem manajemen eksploitatif otoriter (Likert, 1967). Gaya kepemimpinan ini ditandai dengan adanya hubungan anggota organisasi yang rendah namun perilaku penugasan yang tinggi. Manajer memberikan tugas yang spesifik pada karyawan dengan melakukan pengawasan yang sangat ketat. Kepemimpinan yang dominan ini memberi ruang bagi manajer untuk melakukan pengelolaan organisasi dengan menekankan pada kekuatan jabatan. 


\section{Perspektif Hermeneutic Structuralist}

Manajer penganut perspektif hermeneutic structuralist akan mengelola organisasi dengan berorientasi misionaris (Mintzberg, 1989). Perhatian utama adalah pada proses yang dilakukan dalam mencapai tujuan. Kecenderungan para manajer ini selalu memastikan bahwa organisasi yang mereka pimpin memiliki struktur dasar yang ditandai dengan kompleksitas, formalitas, dan sentralisasi yang rendah sehingga para anggota organisasi dapat mendesain pekerjaan mereka sesuai dengan tanggung jawab masingmasing. Dengan kerangka kerja seperti ini akan mempermudah dalam pengambilan keputusan karena dilakukan bersama secara harmonis. Dalam matrik pengambilan keputusan stratejik Thomson (1967), model ini masuk dalam kategori pengambilan keputusan kompromi dimana manajer melihat keberhasilan organisasi dalam mencapai tujuan dilihat dari sisi sebab akibat.

Manajemen akan dianggap berhasil dilakukan jika manajer terlibat dalam pencapaian hasil. Manajer akan mendorong para anggota organisasi atau bahkan masyarakat umum dan organisasi terkait lain untuk bekerja sama dalam pencapaian tujuan karena ada kemungkinan mereka juga memiliki pengaruh baik langsung maupun tidak langsung.

Gaya kepemimpinan yang sesuai dengan manajer penganut hermeneutic structuralist adalah gaya coach (pelatih) (Nichols, 1967) dengan sistem manajemen partisipasi kelompok dengan ditandai adanya hubungan antara manajer anggota yang tinggi namun pola perilaku tugas yang rendah (Likert, 1967). Dalam gaya kepemimpinan ini akan tercipta hubungan yang erat antar anggota dan rendahnya konflik. Hal ini dikarenakan manajer memfasilitasi individu dalam pengambilan keputusan organisasi.

\section{Kondisi Filosofis yang Koheren dalam Praktik Manajemen}

Pemahaman filosofis bagi manajer dalam menjalankan organisasi dengan menggunakan perspektif epistemologi dan ontologi sering mengalami kendala dan tidak bisa dilakukan secara koheren sehingga diperlukan pemahaman perspektif lain yang dapat menjadi pelengkap ilmu bagi para manajer. Dalam penggunaan perspektif epistemologi (naturalisme dan hermeneutika) dan ontologi (strukturalis dan agensi) yang tidak sesuai dengan praktik manajemen, terdapat rerangka yang filosofis dan metodologis dari Bhaskar (1998) yaitu dengan menggunakan sintesis realisme transendental dan Archer (1995) dengan menggunakan sintesis strukturasi. 
Realisme transendental (Bhaskar, 1998) membuat sebuah sintesis epistemologi dengan menggunakan hubungan sebab akibat sebagai dasar untuk mengungkapkan suatu kejadian pada dunia nyata (praktik). Dasar penggunaan perspektif ini yang pertama bahwa dalam praktik dijalankan pada tiga tingkatan yaitu aktual (adanya peristiwa), empiris (sifat dari peristiwa) dan kedalaman (proses yang mendasari peristiwa). Kedua bahwa dunia praktik merupakan akumulasi dari proses yang berbasis model imajinatif hermeneutia dimana pengetahuan akan digunakan untuk mendalilkan mekanisme sebab akibat dari hipotesis yang ada. Strukturasi sintesis ontologis (Archer, 1995) merupakan perspektif ontologis sebagai upaya untuk menengahi adanya perselisihan strukturalis dan agensi. Pertentangannya adalah apakah agensi dan struktur social saling ketergantungan? Atau saling bergantung namun berbeda? Artinya bahwa struktur sosial merupakan sebab dan konsekuensi adanya agensi (lembaga).

Aplikasi dalam organisasi mengenai adanya perspektif pendukung dalam pemahaman manajer pada epistemologi dan ontlogi yaitu dengan melihat sebab akibat dari suatu peristiwa yang terjadi dalam organisasi. Menganalisis proses dan membuat generalisasi empiris tentang penyebab terjadinya masalah sehingga akan muncul hipotesis awal. Seorang manajer harus terlibat langsung bersama dengan karyawan dalam menangani masalah dengan menganalisis faktor-faktor penyebab baik internal maupun eksternal sehingga penafsiran masalah akan lebih tepat dan mudah menyelesaikannya. Pemahaman dan kemampuan mengidentifikasi masalah dalam organisasi merupakan bentuk dari kemampuan manajer dalam mengembangkan konsep dan perspektif yang terdapat dalam kajian filsafat yang akan memudahkan dalam pengembangan organisasi.

\section{Implikasi dalam Praktik Manajemen}

Dalam dunia keorganisasian yang semakin komplek permasalahnya menuntut seorang manajer untuk dapat memahami filosofis manajemen sehingga dapat megetahui kecenderungan dirinya dan orang lain dalam konteks perspektif epistemologi dan ontologi. Pemahaman ini dapat digunakan oleh manajer untuk meningkatkan kinerja dan memahami model manajemen yang baik dengan proposisi sebagai berikut:

Pertama, manajer yang baik akan mengenali keterbatasan dua dimensi dalam organisasi yaitu dimensi kognitif rasional obyektif dan dimensi komunikatif rasional (makna normatif) dalam organisasi baik secara teoritis maupun realitas. Pemahaman ini sangat diperlukan bagi manajer untuk menyelesaikan konflik yang sering muncul dalam 
organisasi sehingga dapat memberikan kenyamanan bagi anggota organisasi dalam bekerja.

Kedua, manajer yang baik tidak akan memiliki kekakuan dalam memilih pola pengelolaan organisasi dan tidak memiliki sikap arogan dengan menganggap bahwa semua masalah dapat terselesekan tanpa bantuan orang lain. Manajer harus peka terhadap penyebab suatu masalah yang timbul dengan siap dengan solusi dan konsekuensi. Keterlibatan seorang manajer dalam setiap lini sangat diperlukan sehingga tujuan organisasi bias terawasi dengan baik.

Ketiga, manajer yang baik akan dapat memahami dan mampu mengevaluasi mengenai perspektif epistemologi dan ontologi. Seorang manajer yang baik tidak akan menghindar jika pola yang diterapkan lebih buruk dari konsep yang ditawarkan dengan pendekatan epistemologi dan ontologi dan termotivasi untuk memperbaiki. Penerimaan akan konstruksi baru yang lebih baik akan menigkatkan kmampuan seorang manajer dalam mengimplementasikan strategi serta memiliki toleransi yang tinggi dalam menghadapi konflik organisasi.

\section{SIMPULAN}

Empat perspektif dari bentukan epistemologi dan ontologi memberikan rerangka bagi manajemen untuk mengetahui bagaimana mereka bertindak sebagai pengelola sebuah organisasi. Perspektif ini sebagai bentuk dasar penalaran manajer dalam bertindak dan bagaimana menilai perilaku individu dalam organisasi.

Manajemen akan dianggap baik jika telah dikonfrontasikan dengan berbagai pola yang sudah dianggap ideal. Dalam pelaksanaan manajemen yang baik menuntut manajer untuk mengakui dan menyadari apabila pola yang dilakukan tidak sesuai dan belum ideal setelah dikonfrontasikan dengan pola-pola lain. Manajer terlibat diskusi dengan para penganut pola pengelolaan organisasi yang berbeda dengan pola yang selama ini digunakan, sehingga terjadi koreksi ketika perlu adanya pembenahan bahkan penggantian sistem lama. Dan terakhir, manajer juga harus memahami teori-teori yang ada sehingga dapat membandingkan dengan komprehensif dan akan dapat menerima standar terbaik dalam penggunaan model pengelolaan organisasi. 


\section{Referensi}

Archer, M.S. 1996. "Social integration and system integration: developing the distinction", Sociology, Vol. 30 No. 4, pp. 679-99.

Bhaskar, R. 1998. The Possibility of Naturalism: A Philosophical Critique of the Contemporary Human Sciences, 3rd ed., Routledge, London.

Dixon, J. 2002. Responses to Governance: Governing Corporations, Societies and the World. Praeger, Westport, CT.

Dixon, J. and Dogan, R. 2002. Hierarchies, Networks and Markets: Responses to Societal Governance Failures, Administrative Theory and Praxis. Vol. 24 No. 1, pp. 175-96.

Dixon, J. and Dogan, R. 2003. A Philosophical Investigation of Corporate Governance Failure. The Journal of The Philosophy of Management, Forth Coming.

Gabriele Lakomski, Colin W. Evers, 2011, Analytic Philosophy and Organization Theory: Philosophical Problems and Scientific Solutions, Research in the Sociology of Organizations. Vol. 32 pp. 23-54

Hollis, M. 1994. The Philosophy of Social Science, Cambridge University Press, Cambridge.

John Dixon, Rhys Dogan, 2003. Corporate Decision Making: Contending Perspectives and Their Governance Implications, Corporate Governance. The International Journal of Business in Society. Vol. 3 Iss 1 pp. 39-57

Judistira, Garna K. 2006. Filsafat Ilmu. Bandung: Judistira Garna Foundation dan Primaco Akademika.

Likert, R. 1967. The Human Organization: Its Management and Value, McGraw-Hill, New York, NY.

Nichols, J.R. 1986. "Congruent Leadership", Leadership \& Organization Development Journal. Vol. 7 No. 1, pp. 27-31.

Ricoeur, Paul. 2006. Hermeneutika Ilmu Sosial. Yogyakarta: Kreasi Wacana.

Salmon, Merrilee, John Earman, Clark Glymour, James G. Lenno, Peter Machamer, J.E. McGuire, John D. Norton, Wesley C. Salmon, Kenneth F. Schaffner. 1992. Introduction to the Philosophy of Science. USA: Prentice-Hall.

Santoso, Heri dan Listiyono Santoso. 2003. Filsafat Ilmu Sosial. Yogyakarata: Gama Media.

Susanto, Astrid S. 1976. Filsafat Komunikasi. Bandung: Bina Cipta.

Thompson, J.D. 1967. Organizations in Action. McGraw-Hill, New York, NY. 
Trevor H. Maddock. 1994. Three Dogmas of Materialist Pragmatism: A Critique of a Recent Attempt to Provide a Science of Educational Administration. Journal of Educational Administration. Vol. 32 Iss 4 pp. 5-27

Weber, M. 1947. The Theory of Social and Economic Organization, (trans. Henderson, A.M. andParsons, T.) (originally published in 1915). Free Press, New York, NY.

$\underline{\text { www.wikipedia.com }}$

www.google.com 


\section{LAMPIRAN}

\section{PEDOMAN PENULISAN ARTIKEL PADA JURNAL "FOKUS BISNIS" STIE PUTRA BANGSA}

Berikut ini ketentuan-ketentuan mengenai sistematika penulisan, format penulisan, tabel, gambar, dan referensi sebagai pedoman penulisan artikel pada Jurnal "Fokus Bisnis" STIE Putra Bangsa Kebumen.

\section{Sistematika Penulisan}

a. Abstrak/Sinopsis, bagian ini memuat ringkasan riset, antara lain mengenai: masalah riset, tujuan, metode dan kontribusi hasil riset. Abstrak disajikan di awal teks dan terdiri antara 150-400 kata. Abstrak diikuti dengan sedikitnya empat kata kunci (keyword) untuk memudahkan penyusunan indeks artikel.

b. Pendahuluan, menguraikan latar belakang (motivasi) riset, rumusan masalah riset dan pernyataan tujuan.

c. Kerangka Teoritis dan Pengembangan Hipotesis, memaparkan kerangka teori berdasarkan telaah literatur yang menjadi landasan logis untuk mengembangkan hipotesis atau proposisi riset dan model riset

d. Metode Riset, memuat metode seleksi dan pengumpulan data, pengukuran dan definisi operasional variabel dan metode analisis data.

e. Pembahasan dan Kesimpulan, berisi pembahasan mengenai temuan dan kesimpulan riset

f. Implikasi dan keterbatasan, menjelaskan implikasi temuan dan keterbatasan riset serta jika perlu saran yang dikemukakan peneliti untuk riset yang akan datang

g. Daftar Referensi, memuat sumber-sumber yang dikutip di dalam penulisan artikel. Hanya sumber yang diacu yang dimuat dalam referensi ini.

h. Lampiran, memuat tabel, gambar, dan instrument riset yang digunakan

\section{Format Penulisan}

a. Panjang artikel tidak lebih dari 7.000 kata (dengan jenis huruf Times New Roman ukuran 12) atau antara $5 \mathrm{~s} / \mathrm{d} 20$ halaman kuarto.

b. Margin atas, bawah, kiri dan kanan sekurang-kurangnya 1 inchi.

c. Halaman muka setidaknya menyebutkan judul artikel dan identitas penulis. 
d. Semua halaman, termasuk tabel, lampiran dan referensi harus diberi nomor urut halaman.

\section{Kutipan dan Referensi}

Kutipan dalam teks sebaiknya ditulis kurung buka dan kurung tutup yang menyebutkan nama akhir penulis, tahun tanpa koma, dan nomor halaman jika dipandang perlu, Contoh:

a. Sumber kutipan dengan penulis (McLeod, 2004). Jika disertai nomor halaman (McLeod 2004 : 423)

b. Satu sumber kutipan dengan dua penulis (McLeod dan Schell, 2004)

c. Satu sumber kutipan dengan lebih dari dua penulis (McLeod dkk, 2004)

d. Dua sumber kutipan dengan penulis yang berbeda (McLeod, 2004; Schell 2005)

e. Dua sumber kutipan dengan penulis yang sama (McLeod 2004, 2005). Jika tahun publikasi sama (McLeod 2004a, 2004b) 